\title{
Waste Management at the Local Level in the EU and Ukraine
}

\author{
Viktor Ladychenko ${ }^{1}$, Olha Melnychuk ${ }^{2}$, Liudmyla Golovko ${ }^{3}$, Oksana Burmak ${ }^{4}$
}

\begin{abstract}
The purpose of this article is to provide an overview of theoretical and practical issues related to the implementation of the responsibilities of bodies of local self-government for the management of solid municipal waste according to the Waste Framework Directive. Experience of EU Member States in this sphere was studied. The state of adaptation of Ukrainian legislation to the requirements of the European Union in the field of waste management has been investigated and proposals for implementation of experience of EU member states were made.
\end{abstract}

Keywords: EU waste policy, EU law, waste management, municipal waste, adaptation of Ukrainian legislation to EU law

\section{EU Waste Policy and Legislation}

Waste, including toxic and hazardous waste, is an inevitable consequence of economic activity. To ensure an ecological balance and a sufficient quality of life in the future, there is now, as never before, an urgent need for rational waste management and waste prevention. It is quite understandable, that landfills are no longer a viable solution for waste disposal. Waste incineration is also not a satisfactory solution due to environmental emissions and highly concentrated pollutants. Prevention of waste generation and reuse of goods is much better solution.

A very ambitious waste policy and legislation has been introduced in the EU over the last 30 years. EU approach represents the departure from traditional thinking about waste as an unwanted burden. Waste is now seen as a valuable resource. The long-term goal of EU waste policy is to transform Europe into a resource efficient society with maximum recycling of the waste, waste generation reduction and using waste as valuable resource where possible. The goal is to achieve much higher levels of utilization and minimize the extraction of additional natural resources.

The Waste Framework Directive provides a framework for coordinating waste management in EU Member States in order to limit waste generation and to optimize waste management and disposal. The EU's approach to waste management is based on a waste hierarchy. EU legislation establishes the priority order for waste management.

\footnotetext{
| 1 Doctor of Law, professor, head of the Department of International Law and Comparative Law of the National University of Life and Environmental Sciences of Ukraine

2Doctor of Law, professor of the Department of Law of Vinnytsia Institute of Trade and Economics of Kyiv National University of Trade and Economics

${ }^{3} \mathrm{PhD}$., associate professor of the Department of International Law and Comparative Law of the National University of Life and Environmental Sciences of Ukraine

${ }^{4}$ Assistant of the Department of Civil and Commercial Law of the National University of Life and Environmental Sciences of Ukraine
} 
Article 4 of the Waste Framework Directive establishes a five-step hierarchy of waste management options which must be applied by EU Member States in the following order of priority:

- waste prevention;

- preparing for re-use;

- recycling;

- other recovery, e.g. energy recovery;

- disposal.

Waste prevention is the most favored option. EU Member States were required to develop waste prevention programs by the end of December 2013, taking into account the entire life cycle of production, i.e. including design, production and distribution, as well as the use and end of life of products.

Several types of waste have been identified in the EU, which need priority and separate legal regulation in order to reduce the environmental impact of these types of waste. Such wastes include: electrical and electronic waste, packaging waste, vehicles, batteries and mining waste. Directives adopted for the regulation of waste management contribute to the efficient use of resources over the years, improve waste collection and waste management, improve product design (using less hazardous substances and increase the content of recyclable materials) and continuously increase recycling rates. Where possible, waste that cannot be recycled or reused should be safely incinerated and environmentally friendly landfills are used only as a last resort.

Waste holders must handle and dispose of waste in accordance with the provisions of the Waste Framework Directive. The Directive requires the establishment of an adequate network of waste management facilities in order to prevent illegal waste management and enables waste holders to act in accordance with the waste hierarchy and the principles of spatial proximity and self-sufficiency. The Directive promotes the efficient use of resources and requires the reuse of goods. Waste is considered as raw material for production (European Commission, 2012).

EU Member States should regularly develop waste management plans and develop waste prevention programs. Waste and waste management is monitored. The costs of disposing of waste must be borne by the holder of waste, by previous holders or by the producers of the product from which the waste came (the polluter pays principle is applied).

Commission Decision 2000/532/EC of 3 May 2000 establishes a list of hazardous waste, defines the difference between hazardous and safe waste. Decision 2000/532 / EC and Annex III of the Waste Framework Directive are now being revised in order to adapt the classification of waste to technical and scientific progress (European Commission, 2019). The following directives have been adopted in the field of waste management: Directive 2006/66/EC of the European Parliament and of the Council on batteries and accumulators and waste batteries and accumulators and repealing Directive 91/157/EEC; Directive 2012/19/EU of the European Parliament and of the Council on waste electrical and electronic equipment; Directive 2011/65/EU of the European Parliament and of the Council on the restriction of the use of certain hazardous substances in electrical and electronic equipment; Directive 2000/53/EC of the European Parliament and of the Council on end-of life vehicles; Directive 2006/21/EC 
of the European Parliament and of the Council on the management of waste from extractive industries and amending Directive 2004/35/EC; European Parliament and Council Directive 94/62/EC on packaging and packaging waste; Council Directive 96/59/EC on the disposal of polychlorinated biphenyls and polychlorinated terphenyls; Council Directive $86 / 278 / \mathrm{EEC}$ on the protection of the environment, and in particular of the soil, when sewage sludge is used in agriculture; Council Directive 1999/31/EC on the landfill of waste.

The following documents have also been adopted in the field of waste management: the Guidelines on the interpretation of the R1 energy efficiency formula for incineration facilities dedicated to the processing of Municipal Solid Waste according to Annex II of Directive 2008/98/EC on waste; the Guidelines for social life cycle assessment of products, etc.

As we can see, today, a comprehensive, integrated system of legislative regulation of waste management has been formed in the European Union. The aforementioned sources of law identify specific tasks and time-bound targets. Dynamic development of waste management, as well as gradual transition of EU Member States to recycling society are observed.

\section{Current State and Prospects for Adaptation of Ukrainian Legislation to the EU Standards in the Sphere of Waste Management}

According to Association Agreement, in the field of waste management Ukraine is obliged to implement three directives: Directive 2008/98/EC on waste, Directive $2006 / 21 / \mathrm{EC}$ on the management of waste from extractive industries and Directive $1999 / 31 / \mathrm{EC}$ on the landfill of waste. In addition, the issue of waste management is also linked to the implementation of Directive $2010 / 75 / \mathrm{EU}$ on industrial emissions (concerning integrated pollution prevention and control). In the long term, Ukraine should move away from the use of landfills as the only way to treat household waste and move towards its sorting, reuse and recycling.

First steps to adapt domestic legislation to EU directives have been made. On November 8, 2017, the Government approved the National Strategy for Waste Management in Ukraine until 2030. The strategy aims to introduce a systematic approach to waste management at the state and regional levels, reducing the volume of waste generation by increasing the volume of their recycling and reuse. Its implementation will be carried out in three stages: the first at period of 2017-2018, the second at period of 2019-2023, the third during years 2024-2030. Implementation of the Strategy is expected to facilitate the implementation of a waste management system on an innovative basis, the development of the relevant legislation, improvement of the state of the environment, as well as sanitary and epidemiological well-being of the population. It is also planned to attract investments in the field of waste management, and thus the creation of modern infrastructure, introduction of the latest technologies, reduction of waste at the landfills, etc. In particular, the Strategy foresees the creation of 800 new facilities for the recycling of materials, utilization and composting of biowaste by 2030, reduction of the total amount of household waste disposal from $95 \%$ to $30 \%$, minimization of the total amount of buried waste from $50 \%$ to $35 \%$ by 2030 , and the 
creation of a network of 50 regional landfills, meeting the requirements of the Directive $1999 / 31 / E C$ on the landfill of waste. In the Strategy, it is also foreseen that an information system will operate to ensure the monitoring and control of waste management, which will include information on the nomenclature and the amount of waste that is generated, processed, recycled and disposed. Business entities that provide such services will also be registered. The creation of the national register of waste sources, capacities in the field of their treatment and reporting system by business entities must be an important instrument of control (Order of the Government, 2017).

On January 1, 2018, the amendment to the Law of Ukraine "On Waste", which prohibits the disposal of unprocessed waste, came into force. According to the changes, bodies of local self-government are prohibited to bury unprocessed household waste at landfills, cities and villages should ensure sorting of garbage by types for recycling and disposal. In addition, the law provides that when local governments or local state administrations choose a sanitation scheme, preference should be given to proposals that provide for a greater degree of recycling or disposal of household waste. Thermal treatment of household waste is allowed only at specially designated enterprises or objects for this purpose. The incineration of household waste is allowed only for energy purposes in order to produce thermal and / or electrical energy. It is prohibited to design, construct and operate landfills for domestic waste without equipping groundwater protection systems and neutralizing biogas. These changes to the legislation in Ukraine were extremely necessary. However, the disadvantage is that the requirements of the new legislation are not being implemented in practice.

The implementation and operation of this standards requires significant investments in the field of household waste management, starting with the organization of separate sorting and ending with the construction of waste processing and incineration plants (Shkurti, 2019). It is necessary to create a system of integrated waste management, involving the private sector both as operators and investors (Shulga, 2019). Although landfills are now playing an important role in the management of domestic waste in Ukraine (Krasnova, 2019), in the future, the role of landfill needs to be changed in order to become an auxiliary element of a comprehensive waste management infrastructure in the long term, serving to remove residual waste which cannot be prevented or otherwise handled.

At the same time, having analyzed the current legislation of Ukraine, we cannot observe significant progress in the sphere of waste management and household waste management in particular. So far, no changes and additions have been made to the Law of Ukraine "On Waste" of March 5, 1998, which would expand and bring into line with Directive 2008/98/EC terminology; separate waste into three categories: hazardous, safe, inert; establish lists of operations for waste disposal and fix other important provisions contained in EU directives. No changes were made to the Tax Code of Ukraine in the part of the environmental tax on waste disposal; technical regulation on waste disposal, which would be based on the norms of the EU directives, was not adopted. So, despite the work done, there is still no actual adaptation of Ukrainian legislation to EU legislation in the field of waste management. As a result, there are 6,000 landfills with a total area of over 9,000 hectares. And this is only according to official statistics of the Ministry of Regional Development. The number of landfills congested is 
256 units $(4.2 \%)$, and 984 units $(16 \%)$ do not meet environmental safety standards. Due to improper solid waste management systems in settlements, as a rule, in the private sector, 26.6 thousand unauthorized landfills covering an area of 0.75 thousand hectares are detected annually, of which 26 thousand unauthorized landfills with an area of 0.68 thousand hectares were eliminated in 2018 (Ministry of Regional Development, 2019).

Waste prevention measures are intended to break the link between economic growth and environmental impacts (Hubanova, 2017). Waste management policy should pay considerable attention to the promotion of product development in order to reduce their environmental impact and waste production. In particular, it is necessary to implement measures that will stimulate the development, production and promotion of reusable, technically long-lasting, safe and recyclable waste products that are environmentally friendly. Economic incentives (privileges, special taxation, etc.), education campaigns can be good examples of such measures. Nowardays in Ukraine such methods of stimulation are not approved at the national level, educational campaigns are mainly organized by environmental organizations and public activists (Tevkun, 2015).

Obviously, Ukraine's fulfillment of its obligations, in particular regarding the approximation of national legislation to EU law, will help to improve both the environment and the image of Ukraine among European countries. Approximation of the national legislation to the legislation of the European Union is a complex and timeconsuming process, since the mere copying of the provisions of the directives into the legislation of Ukraine is insufficient. It must be consistent with the current legal system. It should be emphasized that for the implementation of EU directives in Ukraine it is necessary for Ukraine to set common standards in the field of waste management, to introduce rules that are clear for business entities, which will result in investments in this area and cleaning the environment from waste.

\section{Municipality as a Regulator of Household Waste Management in the EU}

In the EU, bodies of local self-government have considerable authority in the field of solid waste management. The municipality is obliged to provide places for the disposal of all municipal waste produced by physical non-commercial persons in its cadastral territory; it is obliged to provide places for separate collection of components of municipal waste, minimally hazardous waste, paper, plastics, glass, metals and biodegradable waste. The municipality may charge a fee for the collection, transportation, sorting and disposal of municipal waste from individuals under a contract.

One of the key tasks facing local governments is the prevention of waste generation. The main goal of waste prevention is to create conditions for reduction of consumption of materials and to gradually reduce waste production. According to Waste Framework Directive, "prevention" means measures taken before a substance, material or product has become waste, that reduce: a) the quantity of waste, including through the re-use of products or the extension of the life span of products; b) the adverse impacts of the generated waste on the environment and human health; or c) the content of harmful substances in materials and products (article 3 (12)). In view of the above, local authorities should: 
- provide comprehensive information support on this issue and include the issue of waste prevention in educational activities related to environmental protection;

- ensure that all levels of government are effectively involved in prevention of waste;

- support, by all means possible, low-waste and innovative technologies that save raw materials and materials, and support the manufacturing sector in order to optimize production management processes;

- sufficiently inform population at all levels about the available voluntary instruments (voluntary agreements, environmental management systems, eco-labeling, cleaner production) for the gradual extension of their application;

- pay maximum attention to food waste and create conditions for gradual reduction of such waste at all levels of the food cycle (food production, marketing and consumption); - create conditions for stabilization of production of individual components of municipal waste and their further reduction at all levels of public administration;

- create conditions for reduction of production of hazardous waste and construction waste;

- promote the use of service and charity centers and organizations in order to extend the lifespan and reuse of products and materials.

Some of the above goals can be actively pursued by local governments, others need support of other entities. In general, larger cities have more tools to achieve these goals. This is mainly due to the different population structure, infrastructure and financial resources.

Coordination activities should be carried out both between community-level actors and nationwide. Here is a good example used in the Czech Republic in this area. There is coordinated cooperation between the Department of Environmental Protection and the Brno City Council's Social Department within the RE-NAB project, which is the project in the field of waste prevention and further use of functional furniture. In April 2016 in Brno City a project was launched in order to support the use of old furniture, the socalled Furniture Bank. The residents of Brno can donate unnecessary furniture to people who need it. These can be the following goods: wooden, metal or plastic tables, chairs, cabinets, dressers, beds and shelves, all useful furniture, including garden furniture. For hygienic reasons, upholstered furniture is not collected. The four garbage collection centers contain large, covered containers where these items are stored. In addition, the furniture is transported to the stock company SAKO Brno, which maintains a register of currently available furniture, along with photographs. Subsequently, Social Department offers it to the socially needy residents of Brno, who do not have financial resources for the new furniture (The RE-NAB project, 2016). This project prevents waste and saves money from the city budget.

Brno is the first city in the Czech Republic which implements this kind of project. However, such projects are widespread in other EU Member States, in particular Belgium and Austria, where furniture reuse is widespread.

The RetroUse project, which is also being implemented in Brno, started operating in August 2016. The project creates opportunity to reuse old but functional things. These things should be produced before 1989. Thanks to this project, citizens of Brno can extend the product life cycle. The purpose of the project is to distribute goods to those who can continue to use them, as well as to cultural institutions, including museums and 
theaters. Within the framework of the project the population gives away all useful and made before 1989 goods, in particular: books, magazines, tableware and household items, technical equipment, personal documents of interesting people, old photos and films, toys, sports equipment - all goods that can be useful. These items are then given to cultural institutions and to retro lovers. None of the items are traded or become waste. Damaged things are being repaired. Thus, RetroUse is also a social project. Within the framework of this project, the City of Brno cooperates with the American Foundation and other cultural institutions such as the Moravian Gallery, the Brno Technical Museum, and the Institute of Military History (Retro things, 2019).

Coordinated cooperation between city social services and non-profit organizations in reusing used products is important. Here is another good example. The charitable Catholic organization Caritas Plzen operates as a so-called humanitarian warehouse that offers a wide range of new and used goods to the general public. These include children's clothing, women's and men's clothing, workwear, children's shoes and sports equipment, various household goods, tableware, toys, books, plates, baby carriages and furniture. The workers of the charitable organization cooperate with social department of the municipality, labor offices and non-profit organizations in Plzen. In practice, clients come to the warehouse on the recommendation of social service workers (Diocesan Caritas Plzen, 2019).

The aforementioned projects are not only good social projects but also help to prevent waste generation at the local level.

\section{Environmental Education}

In the EU Member States, municipalities are involved in the implementation of regional environmental education strategies, and in some cases they develop their own environmental education concepts. The overall goal of environmental education is to develop the competencies needed for environmentally responsible behavior, that is, behavior that is as environmentally friendly as possible. Environmentally responsible behavior is seen as responsible personal, civic and professional behavior in relation to nature and natural resources, consumer behavior and active influence on the environment, including through legal means (Ladychenko, 2019).

The Project "Searching for New Ways of Information Support in the Implementation of the Czech Waste Prevention Program" is a good example in the sphere of environmental education. The main objectives of the project were as follows: the application and use of scientifically sound methodologies and parameters in order to improve the efficiency of economic and legislative instruments in the field of environmental protection, such as optimization of administrative burden caused by environmental standards, creation and approval of methods for quantifying the economic impact of environmental policy on businesses and households, voluntary agreements aimed at the promotion of innovations in environmental sphere, improvement of effectiveness of environmental education tools and training, and effective implementation of voluntary environmental policy instruments in practice (TAČR project, 2019). Within the project a methodology for integration of waste prevention into school education was developed with the goal to achieve the objective of the Czech Waste Prevention Program, which is to ensure that 
comprehensive information support is provided during the implementation of the Czech Waste Prevention Program, including the introduction of waste prevention into school programs, research programs and educational activities related to environmental protection. In a broader context, it is in line with the introduction of new methods in education, which should contribute to the promotion of the circular economy. The basic principle of a circular economy is to maintain the value added of products in the economic system for as long as possible while reducing the amount of waste. Waste prevention is an essential part of this principle. Waste prevention is firmly anchored in the waste management hierarchy in which it is in the first place (Methodology for the integration of waste prevention, 2016).

Waste prevention can not only be seen as a waste management segment, but much broader, i.e. across the entire product life cycle. There are also synergistic implications of the social sphere, education, regional development, etc., and education plays a very important role in this process.

\section{Powers of Ukrainian Bodies of Local Self-Government in the Field of Waste Management}

In Ukraine, according to the current legislation, local authorities are responsible for the domestic waste management policy. According to the Law "On Waste", bodies of local self-government in the field of waste management: provide development and approval of schemes of sanitary cleaning of settlements; organization of the collection and disposal of household waste, including the waste of small producers, creation of landfills for their disposal, and organization of separate collection of useful components of this waste; approve local and regional waste management programs and monitor their implementation; take measures to stimulate business entities operating in the sphere of waste management; resolve issues regarding the placement of waste management facilities in their territory; coordinate activities of business entities located in their territory; exercise control over the rational use and safe management of waste on their territory; eliminate unauthorized and uncontrolled landfills; assist in clarification of legislation on waste among the population, create necessary conditions in order to stimulate the involvement of the population in the collection and preparation of separate types of waste as secondary raw materials; grant consent for placement on the territory of a village, settlement or city of places or objects for storage and disposal of waste; monitor compliance by legal entities and individuals with requirements in the field of industrial and household waste management. Local governments should set transparent tariffs for the removal, treatment and disposal of household waste.

Establishment of the obligation to collect, sort and recycle waste for local governments is in line with European standards. However, unfortunately, in Ukraine proper implementation of the obligations entrusted to local authorities by the law on waste is not observed. Therefore, it is necessary to study the experience of the EU member states in the field of household waste management in order to replicate positive experience that has already proven itself in practice (Golovko, 2019).

5.1 There is a number of waste prevention measures applied at the municipal level in the EU member states. However, the application of such measures 
should not be an end in itself (Klimek, 2017). They should reflect the local situation in terms of waste management (Yara, 2018), resource conservation, sustainable consumption, social needs, etc. (Ladychenko, 2018).

In Ukraine, the following problems in the sphere of handling domestic waste could be singled out: about half of landfills for solid wastes do not meet sanitary standards (Gulac, 2019); the lack of a sufficient number of incineration plants (Ladychenko, 2019); absence of obligatory sorting of household waste by the population (Funta, 2016); sanctions against persons who create spontaneous landfills are ineffective (significant number of unauthorized dumps are generated each year); insufficient stimulation of enterprises using secondary raw materials, low level of culture of the population in relation to the use of domestic waste, etc.

The way out of this situation is possible provided the joint work of the legislative and executive branches of power in Ukraine with a view to full and timely fulfillment of the obligations undertaken by Ukraine by signing the Association Agreement between Ukraine and the EU and the annexes to this Agreement. It is also necessary to create proper conditions for the operation of recycling waste materials business.

\section{Conclusions}

In the field of municipal waste management, the main goal should be to prevent the generation of waste at the stage of production, to ensure maximum involvement of waste in civil circulation as secondary raw materials in order to minimize their disposal. The main task is to introduce an efficiently working system of separate waste collection, which allows involving a significant amount of resources in the economic turnover with the maximum economic effect. One of the most important ways to increase the efficiency of resource conservation is the integrated use of waste in various sectors of the economy. Therefore, the main attention at the regional and district levels should be given to the search for ways to reuse waste. That is why the task of creation of economic incentives for the participation of the population in the separate collection of waste, primarily an effective tariff policy is very important. Educational activities also play a significant role in involving citizens in reducing waste generation and sorting of municipal solid waste. Training and awareness-raising campaigns should take place in this sphere.

\section{References}

Commission Decision 2000/532/EC of 3 May 2000 replacing Decision 94/3/EC establishing a list of wastes pursuant to Article 1(a) of Council Directive 75/442/EEC on waste and Council Decision 94/904/EC establishing a list of hazardous waste pursuant to Article 1(4) of Council Directive 91/689/EEC on hazardous waste (notified under document number C(2000) 1147), OJ L 226, 6.9.2000, p. 3-24

Diocesan Caritas Plzen. (2019). Retrieved from: https://www.dchp.cz/

Directive 2008/98/EC of the European Parliament and of the Council of 19 November 2008 on waste and repealing certain Directives, OJ L 312, 22.11.2008, p. 3-30

European Commission. Directorate General Environment. Guidance on the interpretation of key provisions of Directive 2008/98/EC on waste. (2012). Retrieved from https://ec.europa.eu/environment/waste/framework/pdf/guidance_doc.pdf 
European Commission. Waste Framework Directive. (2019). Retrieved from https://ec.europa.eu/environment/waste/framework/list.htm

Funta, R., Golovko, L., Juriš, F. (2016). Európa a európske právo. Bratislava: Iris.

Golovko, L., Yara, O., Kutsevych, M., Hubanova, T. (2019). Environmental Policy Integration in Ukraine and the EU. European Journal of Sustainable Development, Volume 8, № 3, 221-227

Gulac, O., Dubchak, L., Iarmolenko, I., Yanchuk, J. (2019). Cooperation of Ukraine and the European Union in the ecological sector: directions and prospects. European Journal of Sustainable Development, Volume 8, № 1, 22-30.

Hubanova, T., Deineha, M., Yara, O. Socio-economic and legal aspects of environmental crime in Ukraine. Baltic Journal of Economic Studies, 2017, № 5. Vol. 3, 276-280.

Klimek, L. (2017). Mutual Recognition of Judicial Decisions in European Criminal Law. Cham: Springer.

Krasnova, Yu.A., Deineha, M.A., Honcharuk, L.Yu., Svyatchenko, L.O. Ecological court as the guarantee of protection of rights of human and citizens. Bulletin of NAS RK, 2019, № 4, 185-191

Ladychenko, V., Golovko L. (2018). The Right to Access to Environmental Information in Ukraine and the EU. European Journal of sustainable development, Volume 7, № 3, 455-459.

Ladychenko, V., Melnychuk, O., Yara, O., Kanaryk J. (2019). International Mechanism of the Environmental Information Access and Cooperation Framework for Climate Change Protection. European Journal of Sustainable Development, Volume 8, № 4, 131-139

Ladychenko, V., Yara, O., Uliutina, O., Golovko, L. (2019). Environmental Liability in Ukraine and the EU. European Journal of Sustainable Development, Volume 8, № 2, 261-267

Law of Ukraine "On Waste". (1998). Bulletin of the Verkhovna Rada of Ukraine (BB), 1998, № 36-37, p.242

Methodology for the integration of waste prevention into teaching for individual school levels and afterschool education. (2016). Retrieved from: https://www.mzp.cz/C1257458002F0DC7/cz /program_predchazeni_vzniku_odpadu/\$FILE/OODP-metodika_vzdelavani-20170201.pdf

Ministry of Regional Development. State of the domestic waste management industry in Ukraine for 2018. (2019). Retrieved from: http://www.minregion.gov.ua/napryamki-diyalnosti/zhkh/terretory/stansferi-povodzhennya-z-pobutovimi-vidhodami-v-ukrayini-za-2018-rik/

Order of the Government of November 8, 2017 No. 820-p On Approval of the National Strategy for Waste Management in Ukraine until 2030. (2017). Retrieved from: https://www.kmu.gov.ua/ua/npas/250431699

Retro things. (2019). Retrieved from: https://www.retro-use.cz/

Shkurti, A. (2019). Analysis of the Western Balkans power market prices within the entso-e framework. European Journal of Sustainable Development, Volume 8, № 1, 229-236

Shulga, I., Kurylo, V., Gyrenko, I., Savych, S. (2019). Legal Regulation of Energy Safety in Ukraine and the European Union: Problems and Perspective. European Journal of Sustainable Development, Volume 8, № 3, 439-447

TAČR project. "Searching for New Ways of Information Support in the Implementation of the Czech Waste Prevention Program". (2019). Retrieved from: https://www.mzp.cz/cz/program_predchazeni _vzniku_odpadu

Tevkun, T. Littering like in Europe: What Ukraine needs to change. (2015). Retrieved from: https://www.eurointegration.com.ua/experts/2015/11/16/7040585/

The RE-NAB project will provide furniture to the socially needy. (2016). Retrieved from: https://www.brno.cz/brno-aktualne/tiskovy-servis/tiskove-zpravy/a/projekt-re-nab-zajistinabytek-socialne-potrebnym/

Yara, O., Uliutina, O., Golovko, L., Andrushchenko, L. (2018). The EU Water Framework Directive: Challenges and Prospects for Implementation in Ukraine. European Journal of Sustainable development, Volume 7, № 2, 175-182 